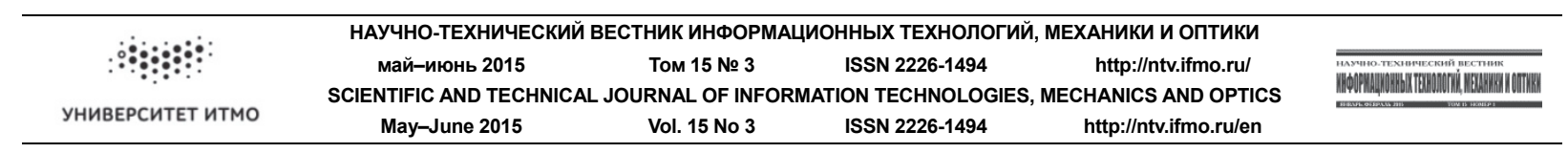

\title{
SELF-CONSISTENT FIELD MODEL OF BRUSHES FORMED BY ROOT-TETHERED DENDRONS E.B. Zhulina ${ }^{\mathrm{a}, \mathrm{b}}$, F.A.M. Leermakers ${ }^{\mathrm{c}, \mathrm{d}}$, O.V. Borisov ${ }^{\mathrm{a}, \mathrm{b}}$
}

a ITMO University, Saint Petersburg, 197101, Russian Federation

b Institute of Macromolecular Compounds RAS, Saint Petersburg, 199004, Russian Federation

${ }^{\mathbf{c}}$ Laboratory of Physical Chemistry and Colloid Science, Wageningen, $6703 \mathrm{HB}$, The Netherlands

${ }^{\text {d }}$ Wageningen University, Wageningen, 6708 PB, The Netherlands

Corresponding author: kzhulina@hotmail.com

Article info

Received 24.02.15, accepted 13.03.15

doi: 10.17586/2226-1494-2015-15-3-493-499

Article in English

For citation: Zhulina E.B., Leermakers F.A.M., Borisov O.V. Self-consistent field model of brushes formed by root-tethered dendrons. Scientific and Technical Journal of Information Technologies, Mechanics and Optics, 2015, vol.15, no. 3, pp. 493-499.

\section{Abstract}

We present an analytical self-consistent field (scf) theory that describes planar brushes formed by regularly branched root-tethered dendrons of the second and third generations. The developed approach gives the possibility for calculation of the scf molecular potential acting at monomers of the tethered chains. In the linear elasticity regime for stretched polymers, the molecular potential has a parabolic shape with the parameter $k$ depending on architectural parameters of tethered macromolecules: polymerization degrees of spacers, branching functionalities, and number of generations. For dendrons of the second generation, we formulate a general equation for parameter $k$ and analyze how variations in the architectural parameters of these dendrons affect the molecular potential. For dendrons of the third generation, an analytical expression for parameter $k$ is available only for symmetric macromolecules with equal lengths of all spacers and equal branching functionalities in all generations. We analyze how the thickness of dendron brush in a good solvent is affected by variations in the chain architecture. Results of the developed scf theory are compared with predictions of boxlike scaling model. We demonstrate that in the limit of high branching functionalities, the results of both approaches become consistent if the value of exponent $\beta$ in boxlike model is put to unity. In conclusion, we briefly discuss the systems to which the developed scf theory is applicable. These are: planar and concave spherical and cylindrical brushes under various solvent conditions (including solvent-free melted brushes) and brush-like layers of ionic (polyelectrolyte) dendrons.

\section{Keywords}

polymer brush, self-consistent field potential, regularly branched dendron, second and third generations.

\section{Acknowledgements}

This research was supported by a Marie Curie International Research Staff Exchange Scheme Fellowship (PIRSES-GA-2013-612562 - POLION) within the 7th European Community Framework Programme and partially supported by the Russian Foundation for Basic Research (Grant 14-03-00372a), by the Department of Chemistry and Material Science of the Russian Academy of Sciences and by the Government of the Russian Federation, Grant 074-U01.

\section{МОДЕЛЬ САМОСОГЛАСОВАННОГО ПОЛЯ ЩЕТОК ИЗ ПРИВИТЫХ КОРНЕВЫМ СЕГМЕНТОМ ДЕНДРОНОВ Е.Б. Жулина ${ }^{\text {a,b }}$, Ф.А.М. Леермакерс ${ }^{c, d}$, О.В. Борисов ${ }^{\text {a,b }}$}

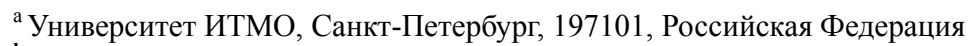

b Институт высокомолекулярных соединений, Санкт-Петербург, 199004, Российская Федерация

c Лаборатория физической химии и коллоидной науки, Вагенинген, 6703 НВ, Нидерланды

d Вагенингенский университет, Вагенинген, 6708 РВ, Нидерланды

Адрес для переписки: kzhulina@hotmail.com

Информация о статье

Поступила в редакцию 24.02 .15 , принята к печати 13.03 .15

doi:10.17586/2226-1494-2015-15-3-493-499

Язык статьи - английский

Ссылка для цитирования: Жулина Е.Б., Леермакерс Ф.А.М., Борисов О.В. Модель самосогласованного поля щеток из привитых корневым сегментом дендронов // Научно-технический вестник информационных технологий, механики и оптики. 2015. Т. 15. № 3. C. $493-499$.

\section{Аннотация}

Представлена аналитическая теория самосогласованного поля, описывающая плоские щетки, образованные регулярно разветвленными дендронами второго и третьего поколений. Развитый подход позволяет вычислить самосогласо- 
ванный молекулярный потенциал, действующий на мономерные звенья привитых цепей. В режиме линейной эластичности для растянутых полимеров молекулярный потенциал имеет параболическую форму с коэффициентом, зависящим от архитектурных параметров привитых макромолекул - степеней полимеризации развязок, степени ветвления и числа поколений.

Для дендронов второго поколения сформулировано общее уравнение для параметра $k$ и проанализировано, как изменения в архитектурных параметрах таких дендронов влияют на молекулярный потенциал. Для дендронов третьего поколения аналитическое выражение для параметра $k$ получено только для симметричных макромолекул с одинаковыми длинами всех развязок и одинаковой степенью ветвления во всех поколениях.

Исследовано, как толщина дендронной щетки в хорошем растворителе варьируется с изменением архитектуры цепи. Результаты развитой теории сопоставлены с предсказаниями скелинговой ящичной модели. Показано, что в пределе высокой степени ветвления результаты обоих подходов становятся согласованными, если величина показателя $\beta$ в ящичной модели равна единице.

В заключении коротко обсуждены системы, к которым применима развитая в работе теория. Они включают плоские и вогнутые сферические и цилиндрические дендронные щетки в растворителях разного качества (в том числе сухие, расплавленные щетки) и щетки из заряженных (полиэлектролитных) дендронов.

\section{Ключевые слова}

полимерная щетка, потенциал самосогласованного поля, регулярно разветвленный дендрон, второе и третье поколение.

\section{Благодарности}

Авторы благодарны поддержке Международной программы по обмену научными кадрами 7-ой рамочной программы Европейского сообщества (грант PIRSES-GA-2013_612562-POLION) и частичной поддержке Российского фонда фундаментальных исследований (грант 14-03-00372a), отделения химии и науки о материалах Российской Академии наук и правительства Российской Федерации (грант 074-U01).

\section{Introduction}

Understanding and controlling adhesive properties of interfaces is of key importance in a range of applications: stabilization of colloid dispersions [1], controlled aggregation of nanoparticles [2], design of antibacterial coatings [3], etc. Tethering macromolecules to interfaces and formation of polymer brushes allows for effective tuning of physical/chemical properties of substrates [4]. For example, a decoration of the sliding surface in artificial joint by biocompatible polymer improves the lubrication in the prosthesis [5]. Modification of surface by tethered branched macromolecules allows to expose the functional groups at the ends of branches to solution in a controlled manner [6]. Natural brush-like structures of branched biopolymers are found on epithelial and microbial cell surfaces [7-9].

The existing theoretical studies focus mostly on brushes of nonionic branched macromolecules with the same architecture and same lengths of spacers [10-18]. Recently, some progress has been achieved in understanding the organization of charged dendron brushes [19] and also of nonionic brushes formed by $\psi$-shaped macromolecules (starlike polymers) with different lengths of the branches. The $\psi$-shaped macromolecules constitute root-tethered dendrons of the first generation $g=1$. The equilibrium features of the brush formed by $\psi$-shaped macromolecules (its thickness, polymer density profile, elastic response to compression, etc.) are fully specified by the self-consistent molecular potential $U(z)$ acting at the monomers at distance $z$ from the grafting surface. It was demonstrated that the molecular potential $U(z)$ arising in the brushes of $\psi$-shaped macromolecules has the parabolic shape inherent for brushes of linear chains, but contains a parameter $k$ which depends on specific architecture of the dendron [11]. If the parameter $k$ is found, and the molecular potential $U(z)$ is specified, calculation of all other characteristics of the $\psi$-brush is straightforward [11].

In this paper we extend the theoretical analysis to brushes formed by more complex macromolecules root-tethered dendrons of the second and third generations and formulate analytical equations for $k$ as a function of the dendron architectural parameters. After solving these equations and following the lines in refs [11] and [18], one could specify the properties of brushes formed by these specifically branched macromolecules.

\section{Model and Results}

Consider a dendron of the second generation $(g=2)$ that comprises of a stem with number of monomers $n_{0} \gg 1, q_{1} \geq 1$ branches of the first generation with number of monomers $n_{1} \gg 1$ each, and $q_{2} \geq 1$ branches of the second generation with number of monomers $n_{2}>1$, emanating from each of $q_{1}$ branching points, see schematic in figure. 


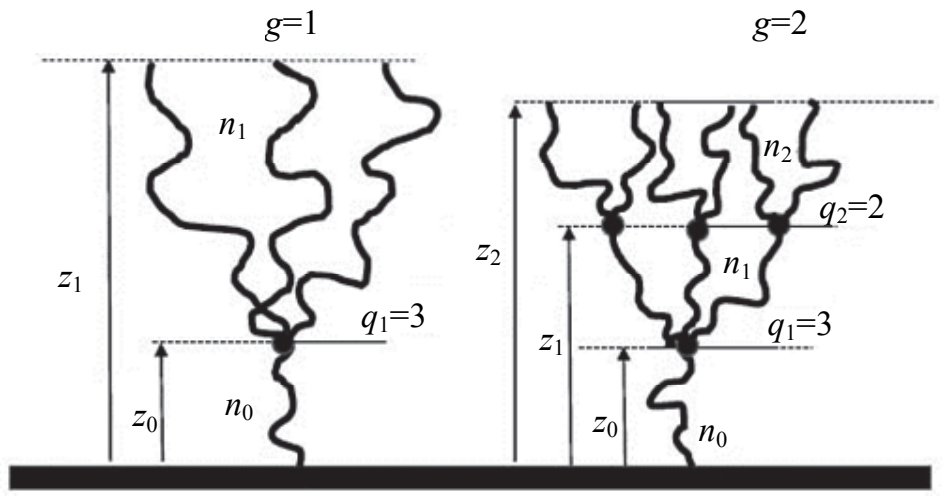

Figure. Schematics of root-tethered dendrons of first ( $g=1)$ and second ( $g=2)$ generations with $q_{1}=3$ and

$q_{2}=2$. Numbers of monomers in spacers and positions of free ends and branching points are indicated

The total number of monomers in the macromolecule is $N=n_{0}+q_{1}\left(n_{1}+q_{2} n_{2}\right)$. The spacers of dendron (the stem and all the branches) are flexible with Kuhn segment length on the same order of magnitude as the monomer size $a$. The dendrons are tethered to inert planar surface by terminal monomer of the stem with grafting density $\sigma$ (which is the number of chains per unit area). The short-range interactions between monomers are repulsive which corresponds to good solvent conditions.

When grafting density $\sigma$ is high enough to insure the predominance of intermolecular repulsions over the intramolecular ones, the dendrons form a polymer brush with preferential elongation of the branches normally to the surface (in the $z$-direction). We focus here on the grafting densities at which all the spacers (including stem of dendrons) exhibit the linear (Gaussian) elasticity. That is, the entropic elastic force arising in an elongated spacer is proportional to its extension (end-to-end distance). Under the conditions of Gaussian chain elasticity, the selfconsistent molecular potential $U(z)$ acting in the brush is given by [11].

$$
\frac{U(z)}{k_{B} T}=\frac{3}{2 a^{2}} k^{2}\left(H^{2}-z^{2}\right)
$$

where $H$ is the brush thickness (cut-off of the polymer density profile), $k$ is the parameter dependent on the dendron architecture, and $k_{B} T$ is the thermal energy.

When the stem and the branches are noticeably extended with respect to their Gaussian sizes $(a \sqrt{n})$ but are still far from their full extension (an), the conformations of macromolecules can be described by the socalled trajectories that specify the most probable height $z(j)$ of monomer with ranking number $j$. The stretching function $E(z)=d z(j) / d j$ specifies local elongation of the trajectory. It is linked to the local (normal) elastic force $P(z)$ in an elongated spacer as $P(z)=3 k_{B} T a^{-2} E(z)$.

Based on earlier findings, [11] the stretching function $E_{2}$ of the free branches in generation $g=2$ of a dendron in the self-consistent parabolic potential $U(z)$ can be presented as

$$
E_{2}\left(z_{2}, z\right)=k \sqrt{z_{2}^{2}-z^{2}}, \quad z_{1} \leq z \leq z_{2}
$$

where $z_{2}$ is the position of the end segment of branch, and $z_{1}$ is the position of branching points of second generation (see right schematic in figure). Equation (2) assures vanishing tension at the end of each free branch, that is, at $z=z_{2}$. By using normalization condition for the free branches, $\int_{z_{1}}^{z_{2}} d z / E_{2}\left(z_{2}, z\right)=n_{2}$, one finds the relationship between position $z_{2}$ of the free end and height $z_{1}$ of the branching point as $z_{2}=z_{1} / \cos \left(k n_{2}\right)$, and

$$
E_{2}\left(z_{1}, z\right)=k \sqrt{\frac{z_{1}^{2}}{\cos ^{2}\left(k n_{2}\right)}-z^{2}}
$$

The stretching function $E_{0}$ of the stem yields

$$
E_{0}\left(z_{0}, z\right)=k \sqrt{\lambda_{0}^{2}-z^{2}}
$$

where $\lambda_{0}$ is the unknown constant. By using normalization condition for the stem, $\int_{0}^{z_{0}} d z / E_{0}\left(z_{0}, z\right)=n_{0}$, one finds constant $\lambda_{0}$ in equation (4) as $\lambda_{0}=z_{0} / \sin \left(k n_{0}\right)$, and 


$$
E_{0}\left(z_{0}, z\right)=k \sqrt{\frac{z_{0}^{2}}{\sin ^{2}\left(k n_{0}\right)}-z^{2}}
$$

Similarly, the stretching function $E_{1}$ of the branches in the first generation yields

$$
E_{1}\left(z_{1}, z\right)=k \sqrt{\lambda_{1}^{2}-z^{2}}
$$

Normalization $\int_{z_{0}}^{z_{1}} d z / E_{1}\left(z_{1}, z\right)=n_{1}$ with $E_{1}\left(z_{1}, z\right)$ specified by equation $(5)$ gives

$$
\arcsin \left(\frac{z_{1}}{\lambda_{1}}\right)-\arcsin \left(\frac{z_{0}}{\lambda_{1}}\right)=k n_{1}
$$

which provides the relationship between $\lambda_{1}, z_{1}$, and $z_{0}$ as

$$
\lambda_{1}^{2}=\frac{z_{1}^{2}+z_{0}^{2}-2 z_{1} z_{0} \cos \left(k n_{1}\right)}{\sin ^{2}\left(k n_{1}\right)}
$$

and determines the stretching function $E_{1}$ as

$$
E_{1}\left(z_{1}, z\right)=k \sqrt{\frac{z_{1}^{2}+z_{0}^{2}-2 z_{1} z_{0} \cos \left(k n_{1}\right)}{\sin ^{2}\left(k n_{1}\right)}-z^{2}}
$$

In the linear elasticity regime, the balance of elastic normal forces at the branching point of a dendron is equivalent to the balance of the stretching functions. That is, at the branching points of the first generation,

$$
E_{0}\left(z_{0}, z_{0}\right)=q_{1} E_{1}\left(z_{1}, z_{0}\right)
$$

or, equivalently,

$$
\sqrt{\frac{z_{0}^{2}}{\sin ^{2}\left(k n_{0}\right)}-z_{0}^{2}}=q_{1} \sqrt{\frac{z_{1}^{2}+z_{0}^{2}-2 z_{1} z_{0} \cos \left(k n_{1}\right)}{\sin ^{2}\left(k n_{1}\right)}-z_{0}^{2}}
$$

which gives the relationship between $z_{1}, z_{0}$, and $k$,

$$
\frac{z_{0}}{\tan \left(k n_{0}\right)}=q_{1} \sqrt{\frac{z_{1}^{2}+z_{0}^{2} \cos ^{2}\left(k n_{1}\right)-2 z_{1} z_{0} \cos \left(k n_{1}\right)}{\sin ^{2}\left(k n_{1}\right)}}=q_{1} \frac{z_{1}-z_{0} \cos \left(k n_{1}\right)}{\sin \left(k n_{1}\right)}
$$
yields

Similarly to equation (7), at each branching point of the second generation balance of the elastic forces

$$
E_{1}\left(z_{1}, z_{1}\right)=q_{2} E_{2}\left(z_{2}, z_{1}\right)
$$

By substituting equations (6) and (3) in the force balance in equation (9), one finds another relationship between $z_{1}, z_{0}$, and $k$,

$$
z_{1}=\frac{z_{0}}{\cos \left(k n_{1}\right)\left[1-q_{2} \tan \left(k n_{2}\right) \tan \left(k n_{1}\right)\right]}
$$

We now have two equations, (10) and (8), to specify three unknown variables: $z_{1}, z_{0}$, and $k$. However, due to the proportionality between $z_{1}$ and $z_{0}$ (which holds only in the linear elasticity regime) these two equations are sufficient to find $k$. By using equation (10) in equation (8), and after some re-arrangements we formulate the final equation for parameter $k$,

$$
q_{1} \tan \left(k n_{0}\right) \frac{\tan \left(k n_{1}\right)+q_{2} \tan \left(k n_{2}\right)}{1-q_{2} \tan \left(k n_{2}\right) \tan \left(k n_{1}\right)}=1
$$

\section{Discussion}

Brush of root-tethered dendrons of second generation $(\boldsymbol{g}=\mathbf{2})$. Equation (11) relates the parameter $k$ in the molecular potential $U(z)$ to architectural parameters $n_{0}, n_{1}, n_{2}, q_{1}$ and $q_{2}$ of a dendron of the second generation $(g=2)$ with total number of monomers $N=n_{0}+q_{1}\left(n_{1}+q_{2} n_{2}\right)$ per macromolecule. Below we consider some special cases of this equation.

Case I. Dendrons with $q_{2}=0$.

When $q_{2}=0$ the system reduces to the case of a $\psi$-shaped macromolecule (i.e., a starlike polymer with $q_{1}$ branches comprising $n_{1}$ monomers each). In this case equation (11) reduces to

$$
q_{1} \tan \left(k n_{0}\right) \tan \left(k n_{1}\right)=1
$$

Furthermore, in the case of the starlike macromolecule with equal lengths of the stem and branches $\left(n_{0}=n_{1}=n\right.$, 
and $\left.q_{1} \equiv q\right)$, and total degree of polymerization $N=(q+1) n$, equation (12) reduces to the result obtained in ref [11],

$$
k=\frac{1}{n} \arctan \frac{1}{\sqrt{q}} \approx \frac{1}{n \sqrt{q}} \quad \text { when } q \gg>1
$$

Case II.Dendrons with $q_{2}=1$.

When $q_{2}=1$ (a starlike dendron with $q_{1}$ branches composed of $n_{1}+n_{2}$ monomers each), equation (11) reduces to the equation

$$
q_{1} \tan \left(k n_{0}\right) \frac{\tan \left(k n_{1}\right)+\tan \left(k n_{2}\right)}{1-\tan \left(k n_{2}\right) \tan \left(k n_{1}\right)}=q_{1} \tan \left(k n_{0}\right) \tan \left(k n_{1}+k n_{2}\right)=1
$$

which is similar to equation (12).

Case III. Symmetric dendrons with equal lengths of all spacers, $n_{1}=n_{2}=n_{0}=n$.

In the case when the stem and all the spacers have the same number of monomers (a symmetric dendron of the second generation with $n_{1}=n_{2}=n_{0}=n$ ), equation (11) reduces to

$$
\frac{q_{1}\left(q_{2}+1\right) \tan ^{2}(k n)}{1-q_{2} \tan ^{2}(k n)}=1
$$

to give the analytical expression for parameter $k$,

$$
k=\frac{1}{n} \arctan \frac{1}{\sqrt{q_{1}+q_{2}+q_{1} q_{2}}}
$$

In the case of equal branching functionality in both generations of the dendron, $q_{1}=q_{2}=q$, the parameter $k$ is given by

$$
k=\frac{1}{n} \arctan \frac{1}{\sqrt{q(q+2)}} \approx \frac{1}{n q} \quad \text { when } q>1
$$

In the case of $q=1$ (a linear chain with number of monomers $N=3 n$ ), equation (15) provides the value of $k$ in the brush of linear chains [11], $k=\arctan \left(3^{-1 / 2}\right) / n=\pi /(6 n)=\pi /(2 N)$.

Brush of root-tethered dendrons of third generation $(g=3)$. Following the same lines as described above for dendrons of the second generation $g=2$ (i.e., by using normalization conditions for stem and all spacers, and implementing force balance in all branching points of the macromolecule), one can formulate an expression for parameter $k$ in the molecular potential $U(z)$ acting in a brush of symmetric root-tethered dendrons of the third generation $(g=3)$. When spacers in all generations of dendron have the same length ( $\left.n_{1}=n_{2}=n_{3}=n_{0}=n\right)$, and branching functionalities are equal $\left(q_{1}=q_{2}=q_{3}=q\right)$, the total molecular weight of the macromolecule is $N=n\left(1+q+q^{2}+q^{3}\right)$, and the value of parameter $k$ is given by

$$
k=\frac{1}{n} \arctan \sqrt{\frac{\left(q^{2}+2 q+3\right)-\sqrt{\left(q^{2}+2 q+3\right)^{2}-4}}{2 q}}
$$

In the case of $q=1$ (a linear chain with number of monomers $N=4 n$ ), equation (16) provides the value of $k$ in the brush of linear chains [11], $k=\arctan (\sqrt{3-\sqrt{8}}) / n=\pi /(8 n)=\pi /(2 N)$.

Brush thickness $\boldsymbol{H}$ in good solvent. Under good solvent conditions the interactions between monomers are dominated by binary monomer-monomer contacts with second virial coefficient $v a^{3}>0$, and the brush thickness $H$ is given by [17].

$$
H / a=\left(\frac{2 a^{2} \sigma v N}{k^{2}}\right)^{1 / 3}
$$

By using equations (13), (15), (16), and (17) we can compare thicknesses of the brushes formed by symmetric dendrons with the same total molecular weight $N$, but different numbers of generations, $q=1$, $g=2$, and $g=3$. Assuming that branching functionality $q \gg>1$ in each dendron is the same, the length of spacer in the case of $q=1$ is $n \approx N / q$, in the case of $g=2, n \approx N / q^{2}$, and in the case of $g=3, n \approx N / q^{3}$. By expanding expressions (13), (15) and (16) at $q>>1$, we find $k \approx \sqrt{q} / N, k \approx q / N$, and $k \approx q^{3 / 2} / N$, respectively. Therefore, according to equation (17) thickness $H$ of the brush formed by dendrons of the first generation $\left(q=1, \psi\right.$-shaped macromolecule) is by factor of $q^{1 / 3}$ larger than that of the brush formed by 
dendrons of the second generation ( $g=2)$. And thickness $H$ of the brush formed by dendrons of the second generation ( $g=2)$ is by factor of $q^{1 / 3}$ larger than that of the brush formed by dendrons of the third generation ( $g=3$ ). These asymptotic results are consistent with earlier predictions formulated in ref [17] for boxlike model with value of exponent $\beta=1$.

\section{Conclusions}

In this study we formulate an analytical self-consistent field (scf) theory of polymer brushes formed by root-tethered flexible dendrons of the second generation with arbitrary length of spacers and branching functionalities. We consider also brushes of symmetric dendrons of the third generation and compare the predictions of the developed scf theory with the results of boxlike scaling model [17]. We demonstrate that the results of scf theory are consistent with the predictions of boxlike model in the limit of high branching functionalities $q>>1$. For moderate values of $q \cong 1$, deviations in values of $\beta$ from $\beta=1$ are expected.

The formulated expressions for parameter $k$ and self-consistent field molecular potential $U(z)$ in equation (1) are applicable not only to dendrons root-tethered to planar substrates, but also to concave (cylindrical and spherical) brushes, and colloidal convex brushes (dendron-decorated collodal particles with radius $R>>H$ ). Moreover, equations (11)-(16) remain valid in a much wider range of conditions than considered in this paper. In particular, they hold in solvents with varying thermodynamic quality (including solvent-free melted brushes), and in both nonionic and charged systems provided that tethered macromolecules remain in the linear elasticity regime of stretching.

\section{References}

1. Guzey D., McClements D.J. Formation, stability and properties of multilayer emulsions for applications in the food industry // Advances in Colloid and Interface Science. 2006. V. 128-130. P. 227-248. doi: 10.1016/j.cis.2006.11.021

2. Groschel A.H., Walther A., Lobling T.I., Schacher F.H., Schmalz H., Müller A.H.E. Guided hierarchical coassembly of soft patchy nanoparticles // Nature. 2013. V. 503. N 7475. P. 247-251. doi: 10.1038/nature12610

3. Krishnamoorthy M., Hakobyan S., Ramstedt M., Gautrot J.E. Surface-initiated polymer brushes in the biomedical field: applications in membrane science, biosensing, cell culture, regenerative medicine and antibacterial coatings // Chemical Reviews. 2014. V. 114. N 21. P. 10976-11026. doi: 10.1021/cr500252u

4. Ayres N. Polymer brushes: applications in biomaterials and nanotechnology // Polymer Chemistry. 2010. V. 1. N 6. P. 769-777. doi: 10.1039/b9py00246d

5. Moro T., Takatori Y., Ishihara K., Konno T., Takigawa Y., Matsushita T., Chung U.-I.L., Nakamura K., Kawaguchi $\mathrm{H}$. Surface grafting of artificial joints with a biocompatible polymer for preventing periprosthetic osteolysis // Nature Materials. 2004. V. 3. N 11. P. 829-836. doi: 10.1038/nmat1233

6. Gillich T., Benetti E.M., Rakhmatullina E., Konradi R., Li W., Zhang A., Schlüter A.D., Textor M. Selfassembly of focal point oligo-catechol ethylene glycol dendrons on titanium oxide surfaces: adsorption kinetics, surface characterization, and nonfouling properties // Journal of American Chemical Society. 2011. V. 133. N 28. P. 10940-10950. doi: 10.1021/ja202760x

7. Vu B., Chen M., Crawford R.J., Ivanova E.P. Bacterial extracellular polysaccharides involved in biofilm formation // Molecules. 2009. V. 14. N 7. P. 2535-2554. doi: 10.3390/molecules 14072535

8. Camesano T.A., Abu-Lail N.I. Heterogeneity in bacterial surface polysaccharides, probed on a singlemolecule basis // Biomacromolecules. 2002. V. 3. N 4. P. 661-667. doi: 10.1021/bm015648y

9. Abu-Lail N.I., Camesano T.A. Role of ionic strength on the relationship of biopolymer conformation, DLVO contributions, and steric interactions to bioadhesion of Pseudomonas putida KT2442 // Biomacromolecules. 2003. V. 4. N 4. P. $1000-1012$. doi: $10.1021 / \mathrm{bm} 034055 \mathrm{f}$

10. Pickett G.T. Classical path analysis of end-grafted dendrimers: dendrimer forest // Macromolecules. 2001. V. 34. N 25. P. 8784-8791. doi: $10.1021 / \mathrm{ma} 010917 \mathrm{y}$

11. Polotsky A.A., Leermakers F.A.M., Zhulina E.B., Birshtein T.M. On the two-population structure of brushes made of arm-grafted polymer stars // Macromolecules. 2012. V. 45. N 7. P. 7260-7273. doi: $10.1021 / \mathrm{ma} 300691 \mathrm{~b}$

12. Merlitz H., Wu C.-X., Sommer J.-U. Starlike polymer brushes // Macromolecules. 2011. V. 44. N 17. P. 7043-7049. doi: $10.1021 / \mathrm{ma} 201363 \mathrm{u}$

13. Merlitz H., Cui W., Wu C.-X., Sommer J.-U. Semianalytical mean-field model for starlike polymer brushes in good solvent // Macromolecules. 2013. V. 46. N 3. P. 1248-1252. doi: 10.1021/ma302417j

14. Cui W., Su C.-F., Merlitz H., Wu C.-X., Sommer J.-U. Structure of dendrimer brushes: mean-field theory and MD simulations // Macromolecules. 2014. V. 47. N 11. P. 3645-3653. doi: 10.1021/ma500129h

15. Kroger M., Peleg O., Halperin A. From dendrimers to dendronized polymers and forests: scaling theory and its limitations // Macromolecules. 2010. V. 43. N 14. P. 6213-6224. doi: 10.1021/ma100861b 
16. Gergidis L.N., Kalogirou A., Vlahos C. Dendritic brushes under good solvent conditions: a simulation study // Langmuir. 2012. V. 28. N 49. P. 17176-17185. doi: 10.1021/la3039957

17. Borisov O.V., Zhulina E.B., Polotsky A.A., Leermakers F.A.M., Birshtein T.M. Interactions between brushes of root-tethered dendrons // Macromolecules. 2014. V. 47. N 19. P. 6932-6945. doi: 10.1021/ma501082p

18. Borisov O.V., Polotsky A.A., Rud O.V., Zhulina E.B., Leermakers F.A.M., Birshtein T.M. Dendron brushes and dendronized polymers: a theoretical outlook // Soft Matter. 2014. V. 10. N 13. P. 2093-2101. doi: $10.1039 / \mathrm{c} 3 \mathrm{sm} 53019 \mathrm{a}$

19. Borisov O.V., Zhulina E.B. Brushes of dendritically-branched polyelectrolytes // Macromolecules. 2015. V. 48. N 5. P. 1499-1508. doi: 10.1021/ma502157r

\section{Ekaterina B. Zhulina}

\section{Franciscus Leermakers}

Oleg V. Borisov

Жулина Екатерина Борисовна

Леермакерс Франс

Борисов Олег Владимирович
D.Sc., Professor, ITMO University, Saint Petersburg, 197101, Russian Federation; Leading researcher, Institute of Macromolecular Compounds RAS, Saint Petersburg, 199004, Russian Federation, kzhulina@hotmail.com

D.Sc., Professor, Professor, Laboratory of Physical Chemistry and Colloid Science, Wageningen, 6703 HB, The Netherlands; Professor, Wageningen University, Wageningen, 6708 PB, The Netherlands, Frans.leermakers@wur.nl

D.Sc., Professor, ITMO University, Saint Petersburg, 197101, Russian Federation; Senior researcher, Institute of Macromolecular Compounds RAS, Saint Petersburg, 199004, Russian Federation, oleg.borisov@hotmail.com

доктор физико-математических наук, профессор, Университет ИТМО, Санкт-Петербург, 197101, Российская Федерация; ведущий научный сотрудник, Институт высокомолекулярных соединений, Санкт-Петербург, 199004, Российская Федерация, kzhulina@hotmail.com

доктор сельскохозяйственных наук, профессор, профессор, Лаборатория физической химии и коллодной науки, Вагенинген, 6703 НВ, Нидерланды; профессор, Вагенингенский Университет, Вагенинген, 6708 РВ, Нидерланды, Frans.leermakers@wur.nl

доктор физико-математических наук, профессор, Университет ИТМО, Санкт-Петербург, 197101, Российская Федерация; старший научный сотрудник, Институт высокомолекулярных соединений, Санкт-Петербург, 199004, Российская Федерация, oleg.borisov@hotmail.com 